Article

\title{
Sustainability of Organizations: The Contribution of Personal Values to Democratic Leadership Behavior Focused on the Sustainability of Organizations
}

\author{
Zlatko Nedelko*(D) and Vojko Potocan
}

Citation: Nedelko, Z.; Potocan, V. Sustainability of Organizations: The Contribution of Personal Values to Democratic Leadership Behavior Focused on the Sustainability of Organizations. Sustainability 2021, 13, 4207. https://doi.org/10.3390/ su13084207

Academic Editor: Virginia Bodolica

Received: 17 March 2021

Accepted: 7 April 2021

Published: 9 April 2021

Publisher's Note: MDPI stays neutral with regard to jurisdictional claims in published maps and institutional affiliations.

Copyright: (c) 2021 by the authors. Licensee MDPI, Basel, Switzerland. This article is an open access article distributed under the terms and conditions of the Creative Commons Attribution (CC BY) license (https:// creativecommons.org/licenses/by/ $4.0 /)$.
Faculty of Economics and Business, University of Maribor, Razlagova Ulica 14, Maribor 2000, Slovenia; vojko.potocan@um.si

* Correspondence: zlatko.nedelko@um.si; Tel.: +386-2-22-90-131

\begin{abstract}
The main purpose of this study was to examine the influence of leaders' personal values on their democratic behavior from a sustainability perspective. We specified and tested the research model, drawing upon modified versions of the theory of basic values and the autocratic-democratic leadership continuum. A total of 208 Slovenian and 196 Austrian leaders' responses were used in hierarchical regression and structural equation modeling analysis. The results reveal a significant and positive influence of collectivistic values in both samples on democratic leadership behavior. A significant and negative effect of individualistic values on democratic leadership behavior is present in Austria, while in Slovenia, the effect is positive but not significant. Based on acknowledged associations between leader's values, leaders' democratic leadership behavior, and sustainable development, we argue that democratic leadership behavior contributes to the sustainable working and behavior of organizations. These results have theoretical implications, indicating how personal values affect leaders' democratic behavior and contribute to the sustainable working and behavior of organizations. The practical implications relate to the strengthening of leaders' democratic behavior in Slovenian and Austrian organizations. In addition, these findings will be helpful in increasing the sustainability of organizations via fostering democratic leadership behavior and its underlying personal values.
\end{abstract}

Keywords: personal values; collectivistic values; democratic behavior; individualistic values; leaders; leadership; sustainable development; sustainability of organizations

\section{Introduction}

A significant body of research investigates the extent to which leaders' personal behavior characteristics affect their behavior and the factors explaining these relationships [1-4]. Several studies have reported that leadership determines the approach to consideration and focal leadership constructs [5-7]. This framework was applied for proposing typical patterns of leaders providing direction, implementing plans, and motivating people $[8,9]$, thus forming several leadership styles [10,11].

Past studies on leadership behavior have focused on leaders' behavior and single behavior factors in different leadership styles [12-14]. At the forefront of most behavior studies is the autocracy-democracy continuum, as the decisive and most exposed characteristic of leaders' behavior [15-17]. Leaders' behavior orientation toward autocracy or democracy characterizes each individual leadership style [15,18-20], which scholars have studied through several behavior theories [17,19].

Initial behavior studies have broadened our understanding of the effect of the characteristics of the environments in which leaders originate or work on their personal behavior orientations $[2,21,22]$. Later studies have focused on the relationships between leaders' work and behavior [23-25]. 
The latest leadership studies have focused on the significance and strength of leaders' values regarding their behavior [20,26] and on the effect of the democratic behavior of leaders on the competitiveness of organizations $[20,27,28]$. The literature reports that the democratic behavior of leaders helps leaders to implement their plans, motivate coworkers, and utilize better managerial ideas in organizations $[6,26]$. In addition, researchers have also paid more attention to international studies in this field, through longitudinal and crosssectional studies, which have covered samples of organizations from heterogeneous [2,13] and similar $[16,29,30]$ environments in the last few decades.

There is less consensus among researchers on how leaders' personal values influence their behavior $[11,31,32]$. According to psychological and sociological cognitions, researchers presume that values affect attitudes, and then attitudes, together with corresponding norms and controls, shape personal behavior [33-35]. Thus, Kemmelmeier et al. and Papagiannakis and Lioukas [36,37] noted that analyzing the "values-attitudes-behavior" causal chain enables a better understanding of values and their impacts on actual behavior.

Recent management research has focused on the direct impact of leaders' personal values [33-35] on their behavior [38,39]. They combine knowledge about values-especially the theory of basic values and value theory [33-35] — and leadership — especially the theory of leadership styles [5-7] and behavior theories of leadership [1-4].

From the current perspective, one of the most challenging tasks for leaders in circumstances of constantly evolving organizations is concern for sustainable development [40-42]. Thus, there have been several studies examining the role of leadership in the creation of the sustainable working behavior of organizations [40] by emphasizing the role of ethical leadership [43,44], servant leadership [43], and transformational leadership [45] in corporate social responsibility. Another stream of research examined sustainability as a function of values [41]. In this context, researchers identified personal values as a driver of propensity for sustainability actions [46], as a catalyst for corporate social responsibility [47], and as a link to pro-environmental behavior [36]. Finally, personal values have been frequently recognized as an important driver of leaders' behavior [3,11,19,32,48].

We can sum up that the literature offers a plethora of studies where personal values are linked with the sustainable working and behavior of leaders, as well as studies linking leaders' behaviors and sustainability $[3,11,19,32,48]$. Despite the considerable number of studies, in light of the crossing silos in leadership research, there are less studies available that discuss how personal values, via democratic leadership behavior, can contribute to sustainable organizational working and behavior. More precisely, in this manuscript we focus on the commonly used autocratic-democratic leadership continuum, while considering personal values through the lenses of individualistic values (IVs) and collectivistic values (CVs), as defined in Schwartz value theory [22]. With this study, we aim to analyze how personal values, via democratic leadership behavior, can contribute to more sustainable organizational working and behavior from areas with different institutional, economic, and cultural backgrounds.

To broaden the scope of these research findings, we focused our research on two Central Europe economies with different paths toward a free-market economy and different institutional, cultural, and value backgrounds. This article reports on research on the influence of CVs and IVs on leaders' democratic behavior in Slovenian and Austrian organizations, considered as a former transition economy and a well-developed market economy, respectively.

Our study draws upon (a) the theory of leadership styles for the examination of leaders focusing on democratic behavior, (b) the theory of basic values for the examination of leaders' CVs and IVs, and (c) value theory for the examination of relations among leaders' personal values and their orientation regarding democratic behavior.

This study offers several distinct contributions to the literature. It contributes to the knowledge about the effects of CVs and IVs on leaders' democratic behavior. The empirical part of the article reveals possible solutions for the development of leaders' democratic behavior in Slovenian and Austrian organizations. It also provides an important starting 
point for increasing the sustainable working of organizations by boosting the personal values of organizational leaders, which can contribute to the more sustainable working and behavior of organizations.

\section{Theoretical Framework and Hypothesis Development}

Leadership authors have reported multiple interpretations of the phenomenon of leadership with which leaders try to apply social science knowledge in solving problems encountered in their organizational role $[10,11,49,50]$.

Leadership literature has examined alternative leadership theories through two perspectives, with the intention to detect (a) the influence of circumstances on leadership in the selected universal and contingent theories and (b) the focus of the leadership construct on the detected trait or behavior theories [28,51]. In that framework, authors have established several leadership styles as typical patterns of leader working and behavior [2,52]. The results of such studies are the basis for a broader exploration of leadership, including indicators for predicting leaders' behavior in organizations.

Psychology has generally defined behavior "as a range of actions and reaction made by humans in conjunction with themselves or their environment" [31]. Leadership researchers consider leaders' behaviors through the dimensions of "Consideration and Initiating Structure" [50,53] and through leadership style $[9,19,35]$. In the development of "leadership styles", researchers use the autocracy versus democracy continuum of leader behavior [12,39]. Initially, authors defined leadership as only authoritarian or democratic; later, they proposed additional leadership styles [32,49,51]. Until today, a dichotomy of autocratic vs. democratic behavior remains a decisive characteristic for the definition and classification of heterogeneous styles of leadership [2,52].

Additionally, psychology has exposed that actual personal behavior is determined by personal and situational variables, which originate in the personality of a leader or in their relations with working environments $[5,49,52]$. These cognitions are utilized in studies about the dominant influence of environmental behavior factors-such as religion, national culture, etc. - on people's behavior $[2,13,54]$. Other studies began with a value-based theory and exposed the decisive impact of leaders' personal values on their behavior $[17,51,55]$.

Personal values include concepts or beliefs that refer to desirable behaviors or end states [23,24,55], transcending specific situations and drawing upon several ground theories about personal, organizational, and societal values [25,38]. As reported by [1], and [26], personal values provide a foundation for the selection of leaders' preferred behavior patterns.

Our consideration of personal values draws from Schwartz' Theory of Basic Values [22]. Schwartz [56] defined a universal structure of 56 basic single values, which he further categorized in ten groups of individual-level sub-dimension values, in four groups of individual-level higher-order dimension values, and finally in two groups of individual-level higher-order dimension values-namely, CVs and IVs. Schwartz' theory was implemented in several studies [57-59] which considered personal values as perceptual filters [9] and drivers [39] in behavior. Ralston and peers [59], as well as Glavas and Kelly [60] revealed how personal values predict managers' behavior orientations.

Less investigated is the real effect of the different value orientations of leaders on their behavior [11,31]. Following the tradition of social psychology [25,61,62], several studies consider relations between the broader construct of the values-attitudes-behavior causal chain $[23,31]$ and the behavior of leaders [63]. Thus, researchers have treated attitudes as psychological responses to a person, object, situation, society, and life. Consequently, values shape attitudes $[11,64]$, and then attitudes, together with subjective norms, perceived behavior controls, and controls, shape actual personal behavior [61,63].

Promising stream of behavior and management studies have considered the direct relationships between the values and behaviors of leaders [38,39]. Thus, Fazio and Glavas and Kelley $[60,63]$ reported that values are the main predictors of human behavior and recommended the utilization of value-behavior relations in leadership studies. Empirical studies from the 1940s to the present have exposed the importance of leaders' democratic 
behavior for organizations and the effect of single democratic behavior factors on leaders' distribution of responsibility, empowering employees, and aiding in the group's decisionmaking process $[10,27,49]$, as well as for high participation in decision-making and power equalization among workers [11,21].

In addition, several empirical studies have reported that CVs and IVs strongly correlate with the democratic behavior of leaders and consequently the democratic orientation of leadership $[2,13,21]$.

Schwartz [56] defined collectivistic orientation as the extent to which a person believes that people are born into groups and that they are expected to look after the interest of their group (e.g., extended family, organization, etc.) and analyzed it through the value groups of benevolence, conformity, and tradition. Studies about individuals caring for the welfare of people with whom one is in frequent personal contact, the restraint of individual actions which harm others and violate social expectations, and commitment to broader social norms noted their effect on increasing the CVs of leaders and the democratic orientation of leadership in organizations in general $[59,60]$. Moreover, empirical studies reported positive correlations between CVs and leaders' democratic behavior, drawing upon their support for the inclusion of co-workers in decision-making processes, the expansion of power and authority among subordinates, and increased cooperation with co-workers [19,27,54]. There are reports in the literature concerning positive correlations in the analysis of job satisfaction, loyalty, emotional commitment, and the engagement of employees and justice, facilitating interpersonal coordination, and commitment in organizations [65-67]. Hence, we hypothesize:

Hypothesis 1. A leader's collectivistic personal values are positively associated with their democratic behavior.

Schwartz [56] defined individualistic orientation as the extent to which a person looks after their self-interest and analyzes this through value groups of power, achievement, hedonism, stimulation, and self-direction. Several empirical studies have reported a negative correlation between IVs and leaders' democratic behavior, because these values are focused on the sustained realization of personal self-interest, the limited participation of coworkers in decision-making, and the prevention of delegation of authority to coworkers [22,59]. There are reports in the literature concerning such negative correlations in analyzing the behavior of leaders oriented on the attainment on social status and prestige, dominance over people and resources, achieving success at all costs, strong stimulation needs, and needs for the sensuous gratification of oneself [65-67].

Hence, we hypothesize:

Hypothesis 2. A leader's individualistic personal values are negatively associated with their democratic behavior.

We studied organizations in Slovenia and Austria as cases of neighboring countries from Central Europe. The selection of Slovenian and Austrian organizations for our study resulted from their close economic cooperation and proclaimed interest in more unified regional economic development $[13,68,69]$. According to leaders' behavior orientations in organizations from both countries, studies have reported diverse results $[2,13,21]$.

The GLOBE study of culture exposed a low power distance, weak individualistic orientation, high degree of masculinity, high uncertainty avoidance, long-term orientation, and weak indulgence - seen as the relaxation of rules and constraints-for individuals in Austria [70], reported on the prevailing orientation of Austrian leaders concerning IVs, which is based on their efforts to achieve results, independent thought, and actions, autonomy, and control over resources. Several researchers argued the prevailing individualistic orientation of leaders in Austrian organizations with historical tradition, a long tradition of free market economy, and in the Germanic behavior tradition [13,71]. Despite the prevailing opinion regarding the dominant influence of IVs on leaders in Austrian' 
organizations in the literature, many authors—such as those of [72]—point to the growing influence of CVs, which is justified by the intensive international cooperation of Austrian firms, the impacts of globalization, the monitoring of the demo-graphic situation, and the implementation of the idea of social responsibility in organizations and society.

The value orientation of Slovenian leaders characterizes a high power distance, a strong collectivistic orientation, a high degree of femininity, high uncertainty avoidance, long-term orientation, and weak indulgence. The authors of [70] explain the predominant collectivistic orientation of Slovenian leaders with the legacy of historical development and the previous "socialist political system" in Slovenia [13,73].

Despite the prevailing opinion about the dominant collectivistic orientation of leaders in Slovenian organizations, studies have reported a growth of IVs in organizations $[68,70,74]$, which is explained as a result of the transition process in Slovenia from the previous political and economic system to a democratic and free market economy-based system, the adaptation of the general values of the system in "central European culture", the stratification of society, and value development within the market economy.

These arguments lead to the following hypotheses about behavior orientation among leaders in Slovenian and Austrian organizations:

Hypothesis 3. A leader's collectivistic personal values more positively and strongly influence the leader's democratic behavior in Slovenian than in Austrian organizations.

Hypothesis 4. A leader's individualistic personal values more negatively and strongly influence the leader's democratic behavior in Austrian than in Slovenian organizations.

\section{Methods}

\subsection{Instrument Used}

A questionnaire aimed at measuring leaders' values, organizational setting, and democratic behavior was used. In the first part, 56 personal values and their descriptions from the Schwartz theory of basic values are listed [56]. In the second part, we asked participants about the characteristics of the organization in which they worked, with the help of items addressing organizational circumstances. The third part consists of items designed to measure leadership behavior via typical items used for addressing the behavior characteristics of leadership styles in the frame of the autocratic and democratic continuum. These items were formulated based on cognitions from the leadership theory and corresponding empirical studies $[2,5,13,18]$ in order to comprehensively examine leaders' behavior. In the last part, the respondents answered several typical demographic questions that are commonly used in business research $[35,75]$. The respondents put in their age and gender. Education level was measured using a scale of questions, where respondents had options for education from "secondary school" to "Ph.D.", for position within the organization from "first level" to "upper level" of manager, and for organizational size from "small" to "large". The respondents also had to choose their industry from the NACE classification.

\subsection{Sample and Procedure}

Random sampling was conducted based on GVIN, an official directory of Slovenian organizations [76], and Aurelia, which lists Austrian organizations [77]. We assigned organizations in the sample based on the percentage of organizations according to their size and industry, as provided by the NACE (for Slovenia) and ÖNACE (for Austria) classifications. We included organizations with more than 50 employees, due to the possible non-typical roles of leaders in smaller organizations. Sampling was carried out in such a way as to assure representativeness according to the typology according to the NACE classification and organizational size based on official statistics. An exception was made for organizational size, as we excluded organizations with fewer than 50 employees. Regarding the gender ratio, we only estimated it over the thumb, while, in terms of employee position, 
the focus was on managers of all hierarchical levels. Based on the demographic statistics of the returned responses, we may conclude that our sample is convenient. All the leaders participated voluntarily in the survey. The same questionnaire was used in both countries, while different administration modes were used in both countries. In Slovenia, the survey was conducted in 2016, and in Austria it was conducted in 2017.

In Slovenia, the survey was conducted by telephone interview; we used a list of contacts from the organizations selected in the sample. Altogether, 700 managers at different positions in the selected Slovenian organizations were contacted via telephone. We obtained 208 usable answers from managers, resulting in a $29.7 \%$ response rate. In Austria, an online survey was conducted. Based on the random sampling of organizations, we obtained up to three direct e-mail addresses from employees in managerial positions in each selected organization. The link to the questionnaire was sent to approximately 1500 managers at different managerial positions in the organizations. We received 215 answers; 196 were used in our analysis, resulting in a $13.07 \%$ response rate.

The demographic characteristics of both samples included in our survey are outlined in Table 1.

Table 1. Demographic characteristics for the Slovenian and Austrian sample.

\begin{tabular}{|c|c|c|}
\hline Variable & Slovenia & Austria \\
\hline Age & 47.28 years & 45.66 years \\
\hline \multicolumn{3}{|l|}{ Age-grouped } \\
\hline Less than 35 years & $18.8 \%$ & $18.4 \%$ \\
\hline $36-45$ years & $22.6 \%$ & $28.9 \%$ \\
\hline $46-55$ years & $39.4 \%$ & $36.3 \%$ \\
\hline More than 55 years & $19.2 \%$ & $16.3 \%$ \\
\hline \multicolumn{3}{|l|}{ Gender } \\
\hline Male & $51.0 \%$ & $78.4 \%$ \\
\hline Female & $49.0 \%$ & $21.6 \%$ \\
\hline \multicolumn{3}{|l|}{ Education } \\
\hline Finished secondary school & $25.1 \%$ & $37.9 \%$ \\
\hline Finished bachelor degree & $71.2 \%$ & $35.3 \%$ \\
\hline Finished master or doctorate degree & $18.8 \%$ & $26.8 \%$ \\
\hline \multicolumn{3}{|l|}{ Position in organization } \\
\hline First-level manager & $2.9 \%$ & $11.6 \%$ \\
\hline Mid-level manager & $26.0 \%$ & $37.9 \%$ \\
\hline Upper-level manager & $71.2 \%$ & $50.5 \%$ \\
\hline \multicolumn{3}{|l|}{ Organization size } \\
\hline Fewer than 49 employees & - & - \\
\hline 50 to 249 employees & $93.3 \%$ & $59.7 \%$ \\
\hline More than 250 employees & $6.7 \%$ & $40.2 \%$ \\
\hline \multicolumn{3}{|l|}{ Industry of organization } \\
\hline A-Agriculture, forestry, and fishing & $2.3 \%$ & $6.1 \%$ \\
\hline B-Mining and quarrying & $0.4 \%$ & $0.7 \%$ \\
\hline C-Manufacturing & $25.5 \%$ & $24.7 \%$ \\
\hline $\begin{array}{l}\text { D-Electricity, gas, steam, and air conditioning } \\
\text { supply }\end{array}$ & $2.2 \%$ & $4.2 \%$ \\
\hline $\begin{array}{l}\text { E-Water supply; sewerage, waste management, } \\
\text { and remediation activities }\end{array}$ & $3.7 \%$ & $1.6 \%$ \\
\hline
\end{tabular}


Table 1. Cont.

\begin{tabular}{lcc}
\hline \multicolumn{1}{c}{ Variable } & Slovenia & Austria \\
\hline F-Construction & $9.8 \%$ & $4.2 \%$ \\
\hline $\begin{array}{l}\text { G-Wholesale and retail trade; repair of motor } \\
\text { vehicles and motorcycles }\end{array}$ & $12.2 \%$ & $7.4 \%$ \\
\hline H-Transportation and storage & $2.9 \%$ & $4.7 \%$ \\
\hline I-Accommodation and food service activities & $3.5 \%$ & $6.8 \%$ \\
\hline J-Information and communication & $2.2 \%$ & $4.2 \%$ \\
\hline K-Financial and insurance activities & $2.2 \%$ & $4.7 \%$ \\
\hline L-Real estate activities & $3.1 \%$ & $2.6 \%$ \\
\hline M-Professional, scientific, and technical activities & $5.0 \%$ & $3.7 \%$ \\
\hline N-Administrative and support service activities & $3.3 \%$ & $3.7 \%$ \\
\hline $\begin{array}{l}\text { O-Public administration and defence; } \\
\text { compulsory social security }\end{array}$ & $2.2 \%$ & $1.6 \%$ \\
\hline P-Education & $3.4 \%$ & $1.1 \%$ \\
\hline Q-Human health and social work activities & $6.9 \%$ & $7.4 \%$ \\
\hline R-Arts, entertainment, and recreation & $1.5 \%$ & $2.1 \%$ \\
\hline S-Other service activities & $7.7 \%$ & $8.4 \%$ \\
\hline
\end{tabular}

For the analysis, we used elements of descriptive statistics, hierarchical regression analysis, and structural equation modeling (SEM). Our analysis consisted of three steps:

- First, we outlined the elements of descriptive statistics (i.e., means and standard deviations) and zero-order correlations between the variables of the interest for the aggregated sample.

- Second, we outlined results from the hierarchical regression analysis regarding the influence of leaders' personal values on their democratic behavior in the Slovenian and Austrian samples. To capture the effect of the control variables, which may have some influence-i.e., age, gender, education, position in the organization, and organizational size-we included them into a hierarchical regression analysis. The control variables were entered first into the analysis, followed by CVs and IVs.

- Third, additionally, a path analysis was conducted in AMOS in order to examine paths between the two groups of personal values and leader democratic behavior to more precisely capture the effect of personal values on democratic behavior.

Since we cannot underestimate or overlook the possible impact of several control variables that are commonly used in behavioral studies, such as age [36], gender [59,78], and industry $[29,53]$, we utilized hierarchical regression analysis in step 2, as suggested by [79], which matches the prevalent research practice [59]. In order to comprehensively address the impact of leaders' personal values on their democratic behavior, we additionally used SEM to examine the pathways, since SEM combines the simultaneous performance of different multivariate techniques. This provides different angles of analysis in social science research, improves the clarification of the specified research model [80], and covers the possible differences in the results between regression analysis in SPSS and SEM in AMOS $[81,82]$. We proceeded to examine the paths between CVs and IVs on one hand and leaders' democratic behavior on the other hand using the SEM technique.

\subsection{Measures}

In line with the purpose of this research, we identified three latent variables; two independent variables-i.e., CVs and IVs-and one dependent variable-leaders' democratic behavior. 


\subsubsection{Individualistic and Collectivistic Personal Values}

Personal values were measured using the Schwartz Value Survey (SVS) [22], which includes a list of 56 single personal values. In the survey, respondents rate each of 56 personal values using a nine-point interval scale, ranging from "opposed to my values" $(-1)$ to "of supreme importance" (7). According to the SVS, we used two dimensions of personal values-namely, CVs and IVs [25]. CVs include the sub-dimensions of benevolence, tradition, and conformity, while IVs include power, achievement, hedonism, and self-direction [22]. The results of the empirical research on portioning the Schwartz model into higher-order dimension values can be found in model validation studies-e.g., [57].

The confirmatory factor analysis (CFA) for the total sample of leaders showed an acceptable fit to the model with one higher-order factor-namely, individualism-and five first-order factors (i.e., sub-dimensions of the values of power, achievement, hedonism, stimulation, and self-direction). $\chi^{2}(\mathrm{~N}=405, \mathrm{df}=244)=2.287, p<0.001 ; \mathrm{CFI}=0.900$; IFI $=0.902 ;$ RMSEA $=0.052$. The Cronbach alpha for IVs is $\alpha=0.823$.

Turning to the collectivism values, the confirmatory factor analysis (CFA) for the total sample of leaders showed an acceptable fit for the model with one higher-order factor-i.e., collectivism - and three first-order factors (i.e., benevolence, tradition, and conformity). $\chi^{2}(\mathrm{~N}=405, \mathrm{df}=164)=372.816, p<0.001 ; \mathrm{CFI}=0.917 ; \mathrm{IFI}=0.919 ;$ RMSEA $=0.052$. The Cronbach alpha for CVs is $\alpha=0.870$.

\subsubsection{Leaders' Democratic Behavior}

We created the dependent latent variable, "leaders' democratic behavior", based on exploratory factorial analysis (EFA), using varimax rotation and principal component extraction. Based on the EFA of 25 items aiming to measure various aspects of management behavior and reliability analysis, nine items accurately and reliably represent leaders' democratic behavior; see [5]. For each item, respondents were asked to indicate their agreement/disagreement with different statements on an eight-point interval scale, ranging from 1 (totally disagree) to 8 (totally agree). Thus, one anchor represents leaders autocratic behavior (1) and the other anchor demonstrates leaders' democratic leadership behavior (8).

Variables are represented accurately and reliably by nine items-i.e., (a) the coordination of work in the organization is based on informal rules and procedures (1-totally disagree; 8-totally agree), (b) the complexity of tasks and/or work prevail in the organization (1-totally disagree; 8 -totally agree), (c) management in the organization is focused on employees and their needs (1-totally disagree; 8-totally agree), (d) group/team work prevails in the organization (1-totally disagree; 8 -totally agree); (e) control in the organization belongs in the domain of employees (1-totally disagree; 8 -totally agree), (f) authority in organization is delegated to the employees (1-totally disagree; 8-totally agree), (g) management in an organization relies on personal power (1-totally disagree; 8 - totally agree), (h) cooperation between management and employees is strong (1-totally disagree; 8 - totally agree), and (i) cooperation between management and employees is informal (1-totally disagree; 8 - totally agree).

The exploratory factor analysis (EFA) for the total sample of leaders showed an acceptable fit for the model with one first-order factor-i.e., democratic leadership behavior. $\chi^{2}(\mathrm{~N}=405, \mathrm{df}=44)=143.769, p<0.001 ; \mathrm{CFI}=0.911 ; \mathrm{IFI}=0.913$; $\mathrm{RMSEA}=0.069$. The Cronbach alpha for democratic leadership was 0.724 . Most of the other studies in this field are confirmatory in their nature, since they use established and previously validated instruments. The authors of [30] use a transformational-transactional typology, reporting coefficients ranging between 0.60 and 0.83 . The author of [19] reported on a study of charismatic leadership coefficients ranging between 0.74 and 0.80 . Compared to other studies and in terms of the exploratory nature of our study, the reliability coefficient of our study is satisfactory. 


\subsection{Research Design and Analysis}

In line with the idea of this research, we examined the influence of leaders' CVs and IVs on their democratic behavior. The research model is depicted in Figure 1.

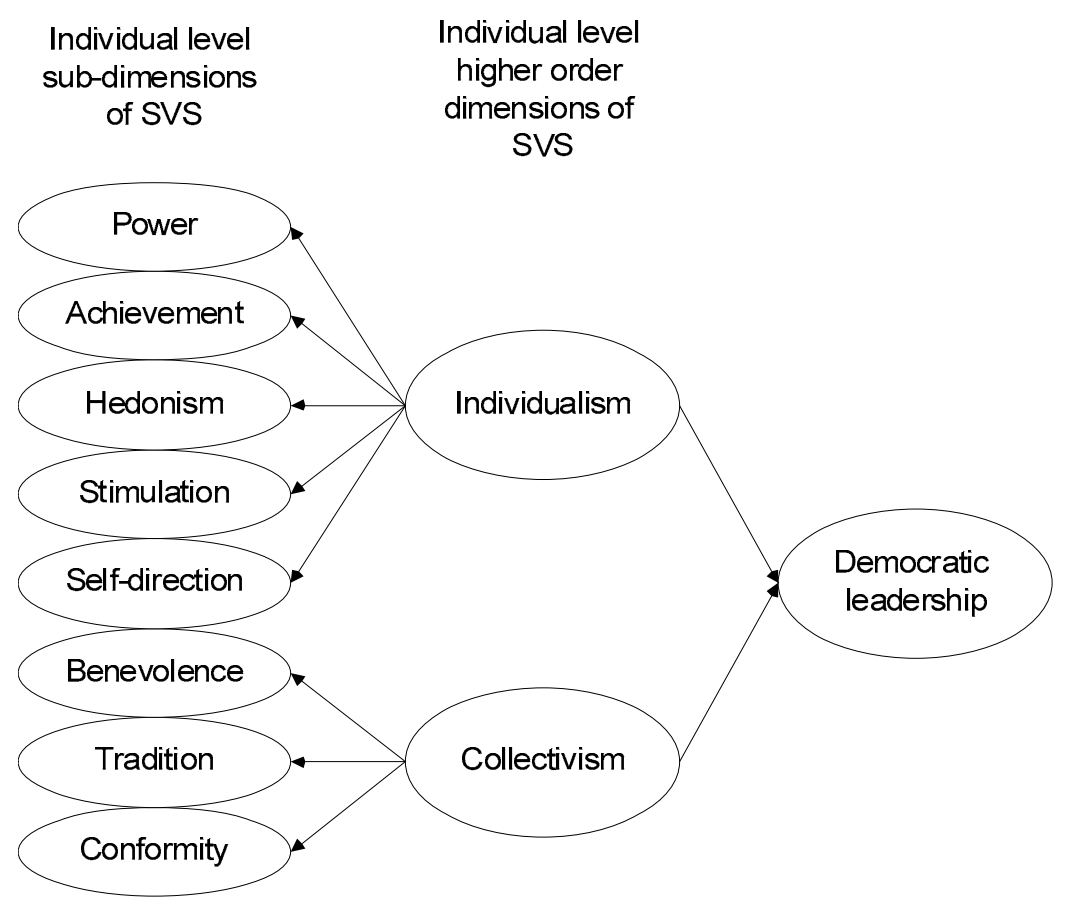

Figure 1. Research model.

Industry of organizations: Respondents had to choose their industry from the NACE classification, offering 22 possible industries. We followed the suggestions of [74] and merged the industry variable with a dichotomous variable with two categories-namely, manufacturing and service. In the manufacturing category, we merged all industries from A to $C$ according to the NACE classification, while in the service category were all the remaining industries, from $\mathrm{D}$ to the end of the list.

Since we have the source of both the independent and dependent variables in one instrument, there is the possibility of bias caused by using a single method of data collection [83]. We estimated the common method variance by using the Harman singlefactor technique in SPSS and the common marker variable technique in AMOS. We used exploratory factor analysis, where all variables were loaded onto a single factor and constrained so that there was no rotation [84]. The newly introduced common latent factor explains $24.60 \%$ of the variance, which is lower than an acceptable $50 \%$ of the variance.

Looking at the correlations between the variables in this study (see Table 2), we can see that they are all far below high correlations $(>0.900)$. This is an indication that a small possibility of common method bias exists [85]. The highest correlation among variables in the study is the one between CVs and IVs $(\beta=0.780 ; p<0.001)$. This reflects the individualism vs. collectivism dichotomy from SVS [86] and reflects that personal values represent individuals' systems of personal values, where the values are inter-related [24,87]. Collinearity statistics were also calculated in the frame of hierarchical regression analysis. VIF (ranging between 1.015 and 1.838) and tolerance values (ranging between 0.544 and 0.994 ) were all in an acceptable range, as VIF values below 10 are acceptable and the tolerance values are higher than 0.100 [88]. It is evident that multicollinearity is not a problem in this study. 
Table 2. Means, standard deviations, and correlations ${ }^{\mathrm{a}}$.

\begin{tabular}{|c|c|c|c|c|c|c|c|c|c|c|c|}
\hline Variable & $\mathbf{M}$ & SD & 1 & 2 & 3 & 4 & 5 & 6 & 7 & 8 & 9 \\
\hline 1. Age & 46.43 & 11.177 & 1 & & & & & & & & \\
\hline 2. Gender & 1.38 & 0.485 & 0.001 & 1 & & & & & & & \\
\hline 3. Education & 4.14 & 0.762 & -0.078 & -0.013 & 1 & & & & & & \\
\hline $\begin{array}{l}\text { 4. Position in } \\
\text { organization }\end{array}$ & 3.46 & 0.787 & $0.179^{* * *}$ & $-0.130 * *$ & $0.095 *$ & 1 & & & & & \\
\hline $\begin{array}{l}\text { 5. Organizational } \\
\text { size }\end{array}$ & 2.12 & 0.530 & -0.027 & $-0.136^{* *}$ & $0.153 * *$ & -0.021 & 1 & & & & \\
\hline 6. Industry & 1.76 & 0.429 & 0.131 ** & $0.110 *$ & -0.058 & -0.020 & -0.046 & 1 & & & \\
\hline 7. Country & 1.45 & 0.498 & -0.058 & $-0.286^{* * *}$ & 0.053 & $-0.105^{*}$ & $0.273^{* * *}$ & -0.081 & 1 & & \\
\hline $\begin{array}{l}\text { 8. Collectivistic } \\
\text { personal values }\end{array}$ & 5.04 & 1.200 & 0.046 & $0.281^{* * *}$ & $-0.139 * *$ & 0.003 & $-0.178^{* * *}$ & 0.050 & $-0.452 * * *$ & 1 & \\
\hline $\begin{array}{l}\text { 9. Individualistic } \\
\text { personal values }\end{array}$ & 4.77 & 1.039 & -0.038 & $0.290 * * *$ & -0.040 & 0.040 & $-0.100 *$ & 0.024 & $-0.420 * * *$ & $0.780 * * *$ & 1 \\
\hline $\begin{array}{l}\text { 10. Democratic } \\
\text { behavior }\end{array}$ & 5.11 & 1.052 & $0.149 * *$ & 0.098 * & -0.066 & $0.174^{* * *}$ & $-0.237^{* * *}$ & $0.123 * *$ & $-0.332 * * *$ & $0.281^{* * *}$ & $0.181 * * *$ \\
\hline
\end{tabular}

In terms of reporting the goodness of fit of the proposed research model (see Figure 1), the fit statistic was calculated for the three-factor measurement model-i.e., IVs, CVs, and leaders' democratic behavior. $\chi^{2}(\mathrm{~N}=405, \mathrm{df}=1722)=3543.915, p<0.001 ; \mathrm{CFI}=0.845$; $\mathrm{NFI}=0.851$; RMSEA $=0.047$. The RMSEA value indicated a good fit between the hypothesized model and data [89,90], since values below 0.05 indicate a good fit [91,92]. Some other measures of goodness of fit, such as CFI and NFI, indicate a lower fit, since the values are below the suggested 0.900 [90]. The authors of [93] claim that the mentioned measures of fit also do not perfectly express the quality of the models; thus, the quality should be judged by other internal and external criteria, such as theoretical grounding. Some additional reasons, which support the adequacy of our model, are (1) that the prevalent research practices often do not consider the reliability of the entire proposed model or possible relations [94,95]; (2) that the findings of our model are in agreement with psychological findings [22,96], (3) that our findings match the results from studies examining values-attitudes-behavior relations $[36,97,98]$. Additionally, the test of closeness of fit-PCLOSE-which tests the hypothesis that the RMSEA is good in the population (Ho, 2006), yielded 0.974 . This value indicates that our proposed model (Figure 1) fits the data well, since our value is well above that suggested by [93]—namely, $>0.5$.

\section{Results}

\section{Descriptive Statistics}

The mean values, standard deviations, and correlations between the variables of the interest are outlined in Table 2.

Some of the associations from Table 2 are noteworthy. First, the country was significantly associated with CVs, IVs, and leaders' democratic behavior. Second, CVs and IVs were significantly associated with leaders' democratic behavior. Third, some personal and organizational demographic variables were significantly associated with leaders' democratic behavior. Based on these significant associations, we separately examined the effects of CVs and IVs on leaders' democratic behavior for Slovenia and Austria.

Table 3 outlines the results from the hierarchical regression analysis. In the first phase of the hierarchical regression analysis, we entered a set of demographic and organizational variables, followed by the CVs and IVs. In Table 4, the results of the pathway analysis between leaders' CVs and IVs and leaders' democratic behavior using SEM are outlined. Control variables were also included in the path analysis in SEM. 
Table 3. Hierarchical regression analysis of the influence of leaders' individualistic and collectivistic values on democratic leadership behavior in Slovenia and Austria.

\begin{tabular}{|c|c|c|c|c|c|c|c|c|}
\hline \multirow{2}{*}{ Model } & \multicolumn{2}{|c|}{ R Square } & \multicolumn{2}{|c|}{$\beta$} & \multicolumn{2}{|c|}{$\mathbf{t}$} & \multicolumn{2}{|c|}{ Sig. } \\
\hline & SLO & AUT & SLO & AUT & SLO & AUT & SLO & AUT \\
\hline $\begin{array}{l}\text { 1. Demographic and } \\
\text { organizational variables }\end{array}$ & 0.071 & 0.071 & & & & & & \\
\hline Age & & & 0.093 & 0.069 & 1.512 & 0.903 & 0.132 & 0.368 \\
\hline Gender & & & -0.048 & 0.029 & -0.777 & 0.376 & 0.438 & 0.707 \\
\hline Education & & & 0.060 & -0.023 & 1.000 & -0.309 & 0.318 & 0.757 \\
\hline Position in organization & & & 0.175 & 0.136 & 2.935 & 1.691 & 0.004 & 0.093 \\
\hline Organizational size & & & -0.057 & -0.189 & -0.954 & -2.558 & 0.341 & 0.011 \\
\hline Industry & & & 0.120 & -0.028 & 1.984 & -0.381 & 0.048 & 0.704 \\
\hline 2. Personal values & 0.132 & 0.097 & & & & & & \\
\hline Collectivistic personal values & & & 0.174 & 0.177 & 2.188 & 1.948 & 0.030 & 0.053 \\
\hline Individualistic personal values & & & 0.109 & -0.188 & 1.363 & -2.068 & 0.174 & 0.040 \\
\hline
\end{tabular}

Table 4. Path analysis of the relations between leaders' individualistic and collectivistic values and democratic leadership behavior for the Slovenian and Austrian sample.

\begin{tabular}{|c|c|c|c|c|c|c|c|c|}
\hline & \multicolumn{2}{|c|}{ R Square } & \multicolumn{2}{|c|}{$\begin{array}{c}\text { Standardized } \\
\text { Coefficients }(\beta)\end{array}$} & \multicolumn{2}{|c|}{ C.R. } & \multicolumn{2}{|c|}{$p$} \\
\hline & SLO & AUT & SLO & AUT & SLO & AUT & SLO & AUT \\
\hline & $0.200 \%$ & $0.230 \%$ & & & & & & \\
\hline Age & & & 0.111 & 0.036 & 1.449 & 0.528 & 0.147 & 0.598 \\
\hline Gender & & & -0.046 & 0.068 & -0.742 & 0.995 & 0.458 & 0.320 \\
\hline Education & & & -0.033 & -0.066 & -0.554 & -0.969 & 0.579 & 0.333 \\
\hline Position in organization & & & 0.187 & 0.208 & 1.838 & 2.918 & 0.066 & 0.004 \\
\hline Organizational size & & & 0.058 & -0.215 & 0.911 & -2.997 & 0.362 & 0.003 \\
\hline Industry & & & 0.101 & -.056 & 1.374 & -0.866 & 0.169 & 0.387 \\
\hline Collectivistic personal values & & & 0.368 & 0.255 & 2.030 & 2.994 & 0.042 & 0.003 \\
\hline Individualistic personal values & & & 0.011 & -0.248 & 0.174 & -3.269 & 0.862 & 0.001 \\
\hline
\end{tabular}

* dependent variable—democratic leadership.

The results for the Slovenian sample show that the demographic and organizational variables accounted for 7.1 percent of the variance in managers' democratic behavior, while in the Austrian sample those variables accounted for 7.1 percent of the variance. The entry of CVs and IVs increased the explained variance in managers' democratic leadership behavior in the Slovenian sample by a further 5.1 percent, to a total of 13.2 percent, while in the Austrian sample, the entry of CVs and IVs dimensions increased the explained variance in managers' democratic behavior only by 2.6 percent, to a total of 9.7 percent. The ANOVA results for the Slovenian sample reveal that the entry of demographic and organizational variables yielded a significant influence on a leader's democratic behavior, $\mathrm{F}(6,253)=3.231$, $p<0.01$. The addition of two dimensions of values also revealed their significant association with leader's democratic behavior, $\mathrm{F}(8,251)=4.757, p<0.001$. Turning to the Austrian sample, the ANOVA results reveal that the demographic and organizational variables yielded a significant influence on the leader's democratic leadership behavior, $\mathrm{F}(6,182)=2.325$, $p<0.05$. The addition of two dimensions of values also made their association with the leader's democratic leadership behavior more significant, $\mathrm{F}(8,180)=2.404, p<0.05$.

Regarding the differences due to the different approaches used-i.e., hierarchical regression analysis (Table 3) and SEM (Table 4) -it is evident that the strengths of the standardized coefficients are higher in SEM than in the hierarchical regression analysis. The directions remain the same disregarding which approach is used. We further comment on the results according to the results in Table 4.

The impact of CVs on democratic leadership behavior is positive and statistically significant in both samples (Slovenia- $\beta=0.368 ; p<0.05$; Austria- $\beta=0.255 ; p<0.01$ ), supporting Hypothesis 1 . The stronger impact of CVs in the Slovenian sample than in the Austrian one provides support for Hypothesis 3. 
The impact of IVs on democratic leadership behavior is positive and non-significant in the Slovenian sample $(\beta=0.011 ; p>0.05)$, while in the Austrian one it is negative and statistically significant $(\beta=-0.248 ; p<0.01)$. This, in general, suggests the rejection of Hypothesis 2. Although, looking through the prism of countries in the study, Hypothesis 2 is rejected for Slovenia, and it can be confirmed for the Austrian sample. Despite the fact that the negative impact of IVs on democratic leadership is stronger for the Austrian sample than for the Slovenian sample, we can only provisionally support Hypothesis 4, as the impact in Slovenia is not negative, as hypothesized.

\section{Discussion}

The relationship between leaders' personal values and leaders' democratic leadership behavior has been highlighted in the literature as a very interesting one $[15,26,28]$. This was an obvious place to start from and it moved the field forward.

The obtained results follow on from previous cognitions about (a) the positive influence of CVs on leaders' democratic behavior-e.g., the authors of $[19,54]$ reported the prevailing influence of CVs on leaders' democratic behavior-and (b) the negative influence of IVs on leaders' democratic behavior-e.g., the authors of [97] reported the decisive role of authority and power for IVs. According to our hierarchical regression analysis, the CVs had a positive and significant influence in Slovenia and the IVs had a negative and significant influence in Austria.

The negative influences of leaders' IVs on leaders' democratic behavior in the Austrian sample matched the established theoretical cognitions from psychology [58,59]. Otherwise, the identified positive correlations in the Slovenian sample have not been previously reported in behavior studies [7,98]. As the outlined positive correlation is weak and nonsignificant, we may only tentatively argue that this positive association was simply random. Looking for other reasons, this could have emerged due to the sample structure or the specifics of the respondents-for instance, the specifics of values for managers. This impact could also stem from the changes related to the impact of EU accession $[75,99]$, changes in value orientation [100], differences in generation cohorts [101,102], or the values of the new generations of business professionals coming to the forefront $[14,103]$.

It is obvious that we need new theoretical knowledge about the characteristics of, role of, and mechanism of influence of these values on democratic behavior-e.g., Why do IVs positively affect the democratic behavior?; How does the positive impact of IVs determine the whole effect of values on the democratic behavior?; Does the mechanism of IVs impact on democratic behavior?

Regarding the explanatory power of the variables of interest, our study showed similar results to previous studies $[20,29,60]$. Oppositely, the results indicate that the demographic variables are stronger predictors of democratic leadership behavior in Austria than in Slovenia, while the personal values are stronger predictors of democratic leadership behavior in the Slovenian sample.

In terms of the personal and organizational demographic variables, considered as controls, we may argue the following. The position of respondents in both Slovenian and Austrian organizations is positively associated with leader's democratic behavior, indicating that employees at hierarchical higher positions are more prone to adopt democratic behavior. This reflects the need for the inclusion of organizational members in the decision-making process, typically present at a higher managerial level, where decisions are complex and unstructured [104]. This reflects democratic leadership behavior [5], where participation in decision-making is the core of democratic leadership. Another significant but negative impact on leaders' democratic behavior in Austria belongs to the impact of organizational size. This reflects that, in smaller organizations, the leaders' behavior is closer to democratic behavior, compared to in larger organizations. For instance, in smaller organizations, a manager can easily attract and include almost everyone in the decision-making process, while in larger organizations, such participation is limited due to the large number of employees, lack of time and skills, etc. The organization's industry 
does not have a substantial impact on leaders' democratic behavior, and only in Slovenia it indicates that, in service organizations, the leader's behavior is more democratic than their behavior in manufacturing organizations. However, the impact is very weak. In the context of the impact of demographic variables on leaders' democratic behavior, it is also important to note that the impact of demographic and organizational variables vary depending on the analysis conducted, such as correlation for aggregated sample of Slovenia and Austria, hierarchical regression analysis and path analysis in SEM, and their impact if becoming weaker when including them in path analysis in SEM. This steams from the simultaneous consideration of the influences of leaders' democratic behavior in our study (i.e., selected demographic variables and CVs and IVs) as well as from the dominance of the impact of CVs and IVs on leaders' democratic behavior, compared to the impact of demographic variables.

Building upon the significant associations between CVs and IVs on one hand, leaders' democratic behavior on the other hand, and the role of leadership in more sustainable organizational working and behavior [40,43-45], we may argue the following. In terms of the contribution of personal values to sustainable development, we may argue that the IVs, which emphasize the concern for "individuals' own interests", contradict the goals of sustainable development $[105,106]$. Those values in our survey also negatively contribute to leaders' democratic behavior, confirming the above assumptions. Inversely, CVs positively contribute to sustainable development, as CVs also put in the forefront the interests of others, going beyond one's own interests $[106,107]$. Those values in our survey positively contribute to leaders' democratic behavior, again supporting the above assumptions. For instance, [108] found that benevolence values, among others, which are one of the pillars of $\mathrm{CVs}$, were related to pro-environmental values.

To sum up, the cognitions about associations between CVs, IVs, leaders' democratic behavior, and sustainable development reveal that democratic leadership behavior contributes to the sustainable working and behavior of organizations.

\subsection{Theoretical Implications}

The theoretical implications of this study may be directed to holistic considerations of the associations between the investigated variables, where the influence of leaders' CVs and IVs on their democratic behavior should be considered simultaneously. We connected together dispersed cognitions concerning (1) the impact of personal values on leadership style $[3,11,31,32],(2)$ the impact of personal values on achieving sustainable working and behavior $[41,46,47,109]$, and (3) cognitions about how leadership contributes to the achievement of sustainable goals via the creation of socially responsible organizations [40,43-45]. We concluded that democratic leadership contributes to the sustainable working and behavior of organizations. This provides a substantial theoretical contribution from a sustainable development perspective.

\subsection{Implications for Practice}

The most notable implications for practice in this research are the following. First, managers in organizations should recognize the role of personal values in shaping leader's behavior. Therefore, we can conclude that the utilization of different behavior initiatives can strengthen the leaders' values, which support the improvement of leaders' democratic behavior. This idea can be based upon the complementary theory [110]; it argues that initiatives targeting single behavior variables produce synergetic effects and complement each other when they are combined [12,111,112]. For instance, organizations can establish democratic behavior norms in business policy and utilize an appropriate "Code of behavior", which are two distinct behavior initiatives, but their combined usage has synergetic effects on the organization stakeholders' behavior [6,37]. If organizations supplement the previous initiatives with education or the training of employees regarding democratic behavior $[8,60,94]$, these different initiatives will likely reinforce each other and may result in improved individual democratic behavior. For instance, the authors of [113] exposed 
the complementary of equity theory and instrumentality theory, and the authors of [8] emphasized the complementary aspects of several levels of leadership for the consideration of leaders' behavior.

Managers should also recognize the importance of democratic behavior in fostering the sustainable working and behavior of organizations. For instance, with fostering democratic behavior the contribution can be at least twofold: first, in following the current trend of empowerment [114,115], downsizing [116], and desire for the inclusion of employees in decision making in organizations [117,118]; second, in responding to calls for the more sustainable working and behavior of organizations $[65,119,120]$. In that context, managers should capitalize on the positive impact of CVs on democratic leadership behavior. One of the CVs sub-dimensions is benevolence values, which focus on the preservation and enhancement of the welfare of people with whom one is in frequent personal contact (SVS) [22]. This implies that heightening the importance of benevolence values will contribute to the more social concern, which is one of the three pillars of sustainable development [121], as well as to the more sustainable working and behavior of organizations.

There might be also organized in-service training, workshops, etc., to increase consciousness of the importance of CVs for democratic behavior and the more sustainable working and behavior of organizations. This corresponds to the notion that concern for organizations' sustainable working and behavior is often only "on paper" [65]. Thus, it is essential to increase consciousness of sustainability in organizations.

Practical implications are also related to the study and comparison of leaders' democratic behavior in an international environment. The study results could also be used for rethinking the previous studies regarding the influence on organizations' efficiency and effectiveness.

Finally, the academic community can also benefit from the results of this study, as it can integrate more content in the curricula about the association between personal values and future business professionals, as Generation $Y$ does not put concern for sustainable development at the forefront of their interests [103].

\subsection{Limitations}

The most significant limitations are the following. First, a minor limitation is the selfassessment approach used for obtaining managers' answers. Since managers' democratic behavior is assessed through their self-perception via values, general conclusions about the actual behavior of managers may be limited. This matches the possible differences between the perceived and actual behavior of an individual [122,123]. Despite the possible influence of participants self-reporting their answers on the results [25,124-126], self-report methodologies are a primary source of data in psychology and especially in social sciences. Many of the findings disseminated to the management community draw from self-report research [84]. The self-assessment approach is also used in empirical research about values, behavior, and ethics $[35,74,75,127]$. The above-mentioned studies consider the use of a self-assessment approach neither as an important limitation nor as a factor that might have an important influence on the results.

Second, another limitation lies in the different administration mode of our survey [128]. We used different modes for administering the survey in Slovenia and Austria due to the availability of funds for surveying. In Slovenia, we had the resources for conducting telephone interviewing, while for Austria we did not. Therefore, we used online surveying in order to obtain answers from employees in organizations. The Slovenian participants provided answers via telephone, while the Austrian participants completed the survey online. Due to the perfect correlation between the mode of survey administration and the country of origin, it was not possible to include the mode of survey administration in the analysis-e.g., as a dummy variable to identify the possible effect of the different modes administering the survey in selected countries. The inability to control the mode of survey administration may have had an impact on the results of the survey and limited the 
conclusions we have drawn from the data. Despite these concerns, management literature does not provide sufficient evidence about the impact of the mixed mode of behavioral studies. Looking beyond management studies, evidence is also rare. For instance, the results regarding the examined behavior of bicyclists, obtained via different modes of survey administration-i.e., phone interview and online survey-do not differ across the two survey samples [129]. Despite some possible problems with the interpretation of data from mixed-mode surveys, we may conclude that neither the management literature nor other literature provide enough evidence, which will reduce the power of the mixed-mode versus single-mode survey in management research.

Third, the next limitation is related to the single-source nature of the data, since managers in the survey rated both their CVs and IVs, as well as their perception about single items concerning democratic leadership behavior, using values. Researchers have considered this issue by reporting results from the common method variances test $[83,84]$ and report that single-source of data is not decisive for their conclusions $[59,127]$. In our study, the common method variance test revealed that bias is not a problem and confirmed the usefulness of our survey.

Fourth, the response rate in our survey was lower than the $50 \%$ regarded as satisfactory in social science research [130-132]. For the telephone survey of Slovenian respondents, the response rate, $29.7 \%$, is satisfactory-e.g., research about personal values and ethics reported response rates lower or similar to ours in their studies, with the lowest being about 15\% [37,59,75]. Typically, online surveys are much less likely to achieve response rates as high as those of surveys administered on paper [133] or using the telephone [134]. The response rate of the Austrian participants answering via web survey-i.e., 13.07\%matches the average response rate in surveys administered online-e.g., the authors of [135] summarized the response rates from thirty-nine studies utilizing a web survey mode and revealed that about one third of the examined studies had response rates below $15 \%$.

Fifth, a minor limitation that may limit the broader generalization of the results comes from the structure of the sample, which is not representative, as smaller organizations and employees in non-managerial positions are not included. Additionally, the gender ratio is only provisional, but despite that, the findings may be considered as reliable and relevant, as in business studies researchers frequently focus on specific viewpoints in their research. For instance, we can find evidence of studies focusing on specific organizational sizesfor instance, on large organizations [136] or small and medium enterprises [137,138]—or studies focusing on managers in organizations [13,14].

\subsection{Future Research Directions}

Several of our potential future research directions are obvious. This paper sets the stage for the further examination of the effect of CVs and IVs on sustainable development, as they have significant influence on leaders' democratic behavior when considering leaders' democratic behavior as a mediator variable. This will help us to additionally clarify how personal values and leaders' democratic behavior simultaneously influence sustainable development-i.e., in the working and behavior of organizations. It will also be beneficial to include more countries in the analysis to verify the pattern of the results beyond the two selected economies. Another promising direction for further research is to clarify how leaders' CVs and IVs influence leaders' individual behavior characteristics; this has not been exposed and examined in detail in previous studies [1,20,29]. This will provide answers to questions such as how achieved values' equilibration shapes their effect on behavior and how single behavioral characteristics contribute to the whole effect of values on behavior. Finally, the identified positive correlation in the Slovenian sample between IVs and democratic leaders' behavior is worth considering in the near future.

\section{Conclusions}

This research addresses the influence of CVs and IVs on leaders' democratic behavior in Slovenian and Austrian organizations from a sustainability perspective. The results 
reveal that, in Slovenia, leaders' CVs are more important than their IVs in shaping their democratic behavior. Based on results calculated from 208 Slovenian and 196 Austrian leaders' responses and using hierarchical regression and SEM, it becomes evident that CVs have a significant and positive influence on democratic leadership behavior in Slovenia and Austria. The impact of IVs is significant and negative in Austria, while in Slovenia the effect is positive and not significant. Based on the associations between CVs, IVs, leaders' democratic behavior, and sustainable development, we can conclude that democratic leadership contributes to the sustainable working and behavior of organizations. Our findings will be useful for future examinations in this field, improving the sustainable working and behavior of organizations, and refreshing the curricula of business schools.

Author Contributions: Conceptualization, Z.N. and V.P.; methodology, Z.N.; validation, Z.N. and V.P.; formal analysis, Z.N. and. V.P.; investigation, Z.N. and. V.P.; resources, Z.N. and. V.P.; data curation, Z.N. and. V.P.; writing-original draft preparation, Z.N. and. V.P.; writing-review and editing, Z.N. and V.P; visualization, Z.N.; supervision, V.P.; funding acquisition, Z.N. and V.P. All authors have read and agreed to the published version of the manuscript.

Funding: The authors acknowledge the project "Entrepreneurship for Innovative Society" (P50023) (financially supported by the Slovenian Research Agency), and the project "Readiness of manufacturing enterprises for Industry 4.0-a comparison of Slovenia and Hungary" (financially supported by the Slovenian Research Agency).

Institutional Review Board Statement: Not applicable.

Informed Consent Statement: Not applicable.

Data Availability Statement: Data are not available.

Conflicts of Interest: The authors declare no conflict of interest.

\section{References}

1. England, G.W.; Lee, R. The Relationship between Managerial Values and Managerial Success in the United States, Japan, India and Australia. J. Appl. Psychol. 1974, 59, 411-419. [CrossRef]

2. House, R.J.; Hanges, P.J.; Javidan, M.; Dorfman, P.W.; Gupta, V. Culture, Leadership, and Organizations: The GLOBE Study of 62 Societies; Sage: Thousand Oaks, CA, USA, 2004.

3. Hambrick, D.C.; Mason, P.A. Upper echelons-the organization as a reflection of its top managers. Acad. Manag. Rev. 1984, 9, 193-206. [CrossRef]

4. Črešnar, R.; Nedelko, Z. Understanding future leaders: How are personal values of generations $\mathrm{Y}$ and $\mathrm{Z}$ tailored to leadership in industry 4.0? Sustainability (Switzerland) 2020, 12. [CrossRef]

5. Tannenbaum, R.; Schmidt, W. How to Choose a Leadership Style. Harv. Bus. Rev. 1973, 51, 58-67.

6. Fein, E.C.; Vasiliu, C.; Tziner, A. Individual Values and Preferred Leadership Behaviors: A Study of Romanian Managers. J. Appl. Social Psychol. 2011, 41, 515-535. [CrossRef]

7. Brodbeck, F.C.; Frese, M.; Akerblom, S.; Audia, G.; Bakacsi, G.; Bendova, H.; Bodega, D.; Bodur, M.; Booth, S.; Brenk, K.; et al. Cultural variation of leadership prototypes across 22 European countries. J. Occup. Organ. Psychol. 2000, 73, 1-29. [CrossRef]

8. Yammarino, F.J.; Dionne, S.D.; Chun, J.U.; Dansereau, F. Leadership and levels of analysis: A state-of-the-science review. Leadersh. Q. 2005, 16, 879-919. [CrossRef]

9. Finkelstein, S.; Hambrick, D. Strategic Leadership: Top Executives and Their Effects on Organizations; West Publishing Company: St. Paul, MN, USA, 1966.

10. Goleman, D. Leadership that gets results. Harv. Bus. Rev. 2000, 78, 78-90.

11. Martindale, N. Leadership Styles: How to handle the different personas. Strateg. Commun. Manag. 2011, 15, 32-35.

12. Drucker, P. Management: Tasks, Responsibilities, Practices; Truman Talley Books: New York, NY, USA, 1986.

13. Lang, R.; Szabo, E.; Catana, G.A.; Konecna, Z.; Skalova, P. Beyond participation?-Leadership ideals of future managers from Central and East European Countries. J. East Eur. Manag. Studies 2013, 18, 482-511. [CrossRef]

14. Cater, T.; Lang, R.; Szabo, E. Values and leadership expectations of future managers: Theoretical basis and methodological approach of the GLOBE Student project. J. East Eur. Manag. Studies 2013, 18, 442-462. [CrossRef]

15. Foster, D. A method of Comparing Follower Satisfaction with the Authoritarian, Democratic, and Laissez-faire Styles of Leadership. Commun. Teacher 2002, 16, 4-6.

16. Hood, J.N. The relationship of leadership style and CEO values to ethical practices in organizations. J. Bus. Ethics 2003, 43, 263-273. [CrossRef] 
17. Yukl, G.; O'Donnell, M.; Taber, T. Influence of leader behaviors on the leader-member exchange relationship. J. Manag. Psychol. 2009, 24, 289-299. [CrossRef]

18. Bass, B.M.; Avolio, B.J. Transformational Leadership Development: Manual for the Multifactor Leadership Questionnaire; Consulting Psychologists: Palo Alto, CA, USA, 1990.

19. Sosik, J.J. The role of personal values in the charismatic leadership of corporate managers: A model and preliminary field study. Leadersh. Q. 2005, 16, 221-244. [CrossRef]

20. Woods, P.A. Democratic leadership: Drawing distinctions with distributed leadership. Int. J. Leadersh. Educ. 2004, 7, 3-26. [CrossRef]

21. Schwartz, S.H. Universals in the content and structure of values-Theoretical advances and empirical tests in 20 countries. Adv. Exp. Soc. Psychol. 1992, 25, 1-65. [CrossRef]

22. Hofstede, G. Culture's Consequences. Comparing Values, Behaviors, Institutions, and Organizations across Nations; SAGE: Thousand Oaks, CA, USA, 2001.

23. Allport, G.W. Pattern and Growth in Personality; Holt, Rinehart \& Winston: New York, NY, USA, 1961.

24. Rokeach, M. The Nature of Human Values; The Free Press: New York, NY, USA, 1973.

25. Schwartz, S.H.; Cieciuch, J.; Vecchione, M.; Davidov, E.; Fischer, R.; Beierlein, C.; Ramos, A.; Verkasalo, M.; Lonnqvist, J.E.; Demirutku, K.; et al. Refining the Theory of Basic Individual Values. J. Personal. Soc. Psychol. 2012, 103, 663-688. [CrossRef]

26. Pastor, J.C.; Mayo, M. Transformational leadership among Spanish upper echelons: The role of managerial values and goal orientation. Leadersh. Organ. Dev. J. 2008, 29, 340-358. [CrossRef]

27. Gastil, J. A Definition and Illustration of Democratic Leadership. Human Relat. 1994, 47, 953-975. [CrossRef]

28. McCleskey, J. Situational, Transformational, and Transactional Leadership and Leadership Development. J. Bus. Stud. Q. 2014, 5, 117-130.

29. Egri, C.P.; Herman, S. Leadership in the North American environmental sector: Values, leadership styles, and contexts of environmental leaders and their organizations. Acad. Manage. J. 2000, 43, 571-604. [CrossRef]

30. Sarros, J.C.; Santora, J.C. Leaders and values: A cross-cultural study. Leadersh. Organ. Dev. J. 2001, 22, 243-248. [CrossRef]

31. Lewin, K.; Lippit, R.; White, R. Patterns of aggressive behavior in experimentally created social climates. J. Soc. Psychol. 1939, 10, 271-301. [CrossRef]

32. Ajzen, I. Attitudes, Personality, and Behavior; Open University Press: Beckshire, UK, 2005.

33. Rokeach, M. Beliefs, Attitudes, and Values; Jossey-Bass: San Francisco, CA, USA, 1968.

34. Schwartz, S. Personal values and socially significant behavior. Int. J. Psychol. 2008, 43, 168.

35. Ralston, D.; Egri, C.; Furrer, O.; Kuo, M.-H.; Li, Y.; Wangenheim, F.; Dabic, M.; Naoumova, I.; Shimizu, K.; de la Garza Carranza, M.; et al. Societal-Level Versus Individual-Level Predictions of Ethical Behavior: A 48-Society Study of Collectivism and Individualism. J. Bus. Ethics 2014, 122, 283-306. [CrossRef]

36. Kemmelmeier, M.; Krol, G.; Kim, Y.H. Values, economics, and proenvironmental attitudes in 22 societies. Cross-Cult. Res. 2002, 36, 256-285. [CrossRef]

37. Papagiannakis, G.; Lioukas, S. Values, attitudes and perceptions of managers as predictors of corporate environmental responsiveness. J. Environ. Manag. 2012, 100, 41-51. [CrossRef]

38. Meglino, B.M.; Ravlin, E.C. Individual values approach in organizations: Concepts, controversies, and research. J. Manag. 1998, 24, 351-389.

39. Lichtenstein, S.; Dade, P. The Shareholder Value Chain: Values, Vision and Shareholder Value Creation. J. Gen. Manag. 2007, 33, 15-31. [CrossRef]

40. De Ruiter, M.; Schaveling, J.; Ciulla, J.B.; Nijhof, A. Leadership and the Creation of Corporate Social Responsibility: An Introduction to the Special Issue. J. Bus. Ethics 2018, 151, 871-874. [CrossRef]

41. Rickaby, M.A.; Glass, J.; Fernie, S. Conceptualizing the Relationship between Personal Values and Sustainability-A TMO Case Study. Adm. Sci. 2020, 10, 15. [CrossRef]

42. Woo, E.-J.; Kang, E. Environmental Issues As an Indispensable Aspect of Sustainable Leadership. Sustainability 2020, $12,7014$. [CrossRef]

43. Christensen, L.J.; Mackey, A.; Whetten, D. Taking Responsibility for Corporate Social Responsibility: The Role of Leaders in Creating, Implementing, Sustaining, or Avoiding Socially Responsible Firm Behaviors. Acad. Manag. Perspect. 2014, 28, 164-178. [CrossRef]

44. Wu, L.-Z.; Kwan, H.K.; Yim, F.H.-K.; Chiu, R.K.; He, X. CEO Ethical Leadership and Corporate Social Responsibility: A Moderated Mediation Model. J. Bus. Ethics 2015, 130, 819-831. [CrossRef]

45. Robertson, J.L. The Nature, Measurement and Nomological Network of Environmentally Specific Transformational Leadership. J. Bus. Ethics 2018, 151, 961-975. [CrossRef]

46. Marcus, J.; MacDonald, H.A.; Sulsky, L.M. Do Personal Values Influence the Propensity for Sustainability Actions? A PolicyCapturing Study. J. Bus. Ethics 2015, 127, 459-478. [CrossRef]

47. Hemingway, C.A. Personal values as a catalyst for corporate social entrepreneurship. J. Bus. Ethics 2005, 60, 233-249. [CrossRef]

48. Cha, S.E.; Edmondson, A.C. When values backfire: Leadership, attribution, and disenchantment in a values-driven organization. Leadersh. Q. 2006, 17, 57-78. [CrossRef]

49. Stogdill, R. Handbook of Leadership; The Free Press: New York, NY, USA, 1974. 
50. Manning, G.; Kurtis, K. The Art of Leadership; McGraw-Hill: New York, NY, USA, 2009.

51. Jago, A. Leadership: Perspectives in Theory and Research. Manag. Sci. 1982, 28, 315-336. [CrossRef]

52. Heller, F.; Yukl, G. Participation, Managerial Decision-Making, and Situational Variables. Organ. Behav. Human Perform. 1969, 4, 227-241. [CrossRef]

53. Fleishman, E.; Burtt, H. Leadership and Supervision in Industry; Ohio State University Press: Columbus, OH, USA, 1966.

54. Fiedler, F.E. A Theory of Leadership Effectiveness; McGraw-Hill Book, Co.: New York, NY, USA, 1967.

55. Debreu, J. Theory of Value: An Axiomatic Analysis of Economic Equilibrium; Yale University: New Haven, CT, USA, 1972.

56. Schwartz, S.H. Are there universal aspects in the structure and contents of human-values. J. Soc. Issues 1994, 50, 19-45. [CrossRef]

57. Schwartz, S.H.; Boehnke, K. Evaluating the structure of human values with confirmatory factor analysis. J. Res. Personal. 2004, 38, 230-255. [CrossRef]

58. Fontaine, J.R.J.; Poortinga, Y.H.; Delbeke, L.; Schwartz, S.H. Structural Equivalence of the Values Domain Across Cultures. J. Cross-Cult. Psychol. 2008, 39, 345-365. [CrossRef]

59. Ralston, D.A.; Egri, C.P.; Reynaud, E.; Srinivasan, N.; Furrer, O.; Brock, D.; Alas, R.; Wangenheim, F.; Darder, F.L.; Kuo, C.; et al. A Twenty-First Century Assessment of Values Across the Global Workforce. J. Bus. Ethics 2011, 104, 1-31. [CrossRef]

60. Glavas, A.; Kelley, K. The Effects of Perceived Corporate Social Responsibility on Employee Attitudes. Bus. Ethics Q. 2014, 24, 165-202. [CrossRef]

61. Eagly, A.; Chaiken, S. Attitude Structure and Function. In Handbook of Social Psychology; Gilbert, D.T., Fiske, S.T., Lindzey, G., Eds.; McGowan-Hill: New York, NY, USA, 1998; pp. 269-322.

62. Wood, W. Attitude Change: Persuasion and Social Influence. Annu. Rev. Psychol. 2000, 51, 539-570. [CrossRef]

63. Fazio, R.H. Multiple Processes by which Attitudes Guide Behavior: The Mode Model as an Integrative Framework. In Advances in Experimental Social Psychology; Zanna, M.P., Ed.; Academic Press: Cambridge, MA, USA, 1990; Volume 23, pp. 75-109.

64. Eagly, A.H.; Chaiken, S. The Psychology of Attitudes; Harcourt Brace Jovanovich: Fort Worth, TX, USA, 1992.

65. Hoque, N.; Rahman, A.R.A.; Molla, R.I.; Noman, A.H.M.; Bhuiyan, M.Z.H. Is corporate social responsibility pursuing pristine business goals for sustainable development? Corp. Soc. Responsib. Environ. Manag. 2018, 25, 1130-1142. [CrossRef]

66. Podsakoff, P.M.; MacKenzie, S.B.; Paine, J.B.; Bachrach, D.G. Organizational Citizenship Behaviors: A Critical Review of the Theoretical and Empirical Literature and Suggestions for Future Research. J. Manag. 2000, 26, 513-563. [CrossRef]

67. Organ, D.W.; Ryan, K. A Meta-analytic review of attitudinal and dispositional predictors of organizational citizenship behavior. Pers. Psychol. 1995, 48, 775-802. [CrossRef]

68. Mrak, M.; Rojec, M.; Silva-Jauregui, C. Slovenia: From Yugoslavia to the European Union.; The World Bank: Washington, DC, USA, 2004.

69. OECD. OECD Economic Surveys: Slovenia; OECD: Paris, France, 2018.

70. Hofstede, G.; Hofstede, G. Dimension Data Matrix. Available online: http://www.geerthofstede.com/dimension-data-matrix (accessed on 1 April 2021).

71. Armbrüster, T. Management and Organization in Germany; Ashgate Publishing Limited: Hampshire, UK, 2005.

72. Szabo, E.; Brodbeck, F.C.; Den Hartog, D.N.; Reber, G.; Weibler, J.; Wunderer, R. The Germanic Europe cluster: Where employees have a voice. J. World Bus. 2002, 37, 55-68. [CrossRef]

73. Musek, J. Personality and Values; Educy: Ljubljana, Slovenia, 1993. (In Slovene)

74. Potocan, V.; Mulej, M.; Nedelko, Z. How economic crises effect employees' attitudes towards socially responsible behavior-Case of Slovenia. J. East Eur. Manag. Studies (JEEMS) 2019, 152-178. [CrossRef]

75. Furrer, O.; Egri, C.P.; Ralston, D.A.; Danis, W.; Reynaud, E.; Naoumova, I.; Molteni, M.; Starkus, A.; Darder, F.L.; Dabic, M.; et al. Attitudes toward Corporate Responsibilities in Western Europe and in Central and East Europe. Manag. Int. Rev. 2010, 50, 379-398. [CrossRef]

76. Bisnode. Bisnode-GVIN. Available online: www.gvin.com (accessed on 15 February 2015).

77. Creditreform. Aurelia-Database. Available online: https://www.creditreform.at/produkte/marketing-services/aurelia.html (accessed on 15 March 2015).

78. Ho, R. Handbook of Univariate and Multivariate Data Analysis and Interpretation with SPSS; Chapman \& Hall/CRC: Boca Raton, FL, USA, 2006.

79. Barry, J.B.; Göran, S. Structural equation modeling in social science research: Issues of validity and reliability in the research process. Eur. Bus. Rev. 2012, 24, 320-330. [CrossRef]

80. Cheng, E.W.L. SEM being more effective than multiple regression in parsimonious model testing for management development research. J. Manag. Dev. 2001, 20, 650-667. [CrossRef]

81. Mahsud, R.; Yukl, G.; Prussia, G. Leader empathy, ethical leadership, and relations-oriented behaviors as antecedents of leader-member exchange quality. J. Manag. Psychol. 2010, 25, 561-577. [CrossRef]

82. Podsakoff, P.M.; MacKenzie, S.B.; Podsakoff, N.P. Sources of method bias in social science research and recommendations on how to control it. Annu. Rev. Psychol. 2012, 63, 539-569. [CrossRef]

83. Podsakoff, P.M.; MacKenzie, S.B.; Lee, J.Y.; Podsakoff, N.P. Common method biases in behavioral research: A critical review of the literature and recommended remedies. J. Appl. Psychol. 2003, 88, 879-903. [CrossRef] [PubMed]

84. Bagozzi, R.P.; Yi, Y.; Phillips, L.W. Assessing Construct Validity in Organizational Research. Adm. Sci. Q. 1991, 36, 421-458. [CrossRef] 
85. Schwartz, S.H. Individualism-Collectivism:Critique and Proposed Refinements. J. Cross-Cult. Psychol. 1990, $21,139-157$. [CrossRef]

86. Stackman, R.W.; Connor, P.E.; Becker, B.W. Sectoral ethos: An investigation of the personal values systems of female and male managers in the public and private sectors. J. Public Adm. Res. Theory 2006, 16, 577-597. [CrossRef]

87. Hair, J.F.; Anderson, R.E.; Tatham, R.L.; Black, W.C. Multivariate Data Analysis with Readings; Prentice-Hall: Englewood Cliffs, NJ, USA, 1998.

88. Hu, L.T.; Bentler, P.M. Cutoff criteria for fit indexes in covariance structure analysis: Conventional criteria versus new alternatives. Struct. Equ. Modeling A Multidiscip. J. 1999, 6, 1-55. [CrossRef]

89. Byrne, B.M. Structural Equation Modeling with AMOS.; Routledge: New York, NY, USA, 2010.

90. Browne, M.W.; Cudeck, R. Single Sample Cross-Validation Indices for Covariance Structures. Multivar. Behav. Res. 1989, 24, 445-455. [CrossRef]

91. MacCallum, R.C.; Browne, M.W.; Sugawara, H.M. Power Analysis and Determination of Sample Size for Covariance Structure Modeling. Psychol. Methods 1996, 1, 130-149. [CrossRef]

92. Jöreskog, K.G.; Sörbom, D. LISREL 8: User's Reference Guide; Scientific Software International: Chicago, IL, USA, 1996.

93. Stern, P.C. Toward a coherent theory of environmentally significant behavior. J. Soc. Issues 2000, 56, 407-424. [CrossRef]

94. Nordlund, A.M.; Garvill, J. Value structures behind proenvironmental behavior. Environ. Behav. 2002, 34, 740-756. [CrossRef]

95. Homer, P.M.; Kahle, L.R. A structural equation test of the value-attitude-behavior hierachy. J. Personal. Soc. Psychol. 1988, 54, 638-646. [CrossRef]

96. Potocan, V.; Nedelko, Z.; Peleckienè, V.; Peleckis, K. Values, environmental concern and economic concern as predictors of enterprise environmental responsiveness. J. Bus. Econ. Manag. 2016, 17, 685-700. [CrossRef]

97. Nedelko, Z.; Peleckienè, V.; Peleckis, K.; Peleckis, K.K.; Lapinskiené, G.; Potocan, V. The impact of economic attitudes on natural and social corporate responsibility-A comparative study of Lithuania and Slovenia. Eng. Econ. 2019, 30, 362-372. [CrossRef]

98. Ronen, S.; Shenkar, O. Clustering countries on attitudinal dimensions: A review and synthesis. Acad. Manag. Rev. 1985, 10, 435-454. [CrossRef]

99. Bakacsi, G.; Sandor, T.; Karacsonyi, A.; Imrek, V. Eastern European cluster: Tradition and transition. J. World Bus. 2002, 37, 69-80. [CrossRef]

100. Jelovac, D.; Van Der Wal, Z.; Jelovac, A. Business and Government Ethics in the 'New' and 'Old' EU: An Empirical Account of Public-Private Value Congruence in Slovenia and the Netherlands. J. Bus. Ethics 2011, 103, 127-141. [CrossRef]

101. Ralston, D.A.; Egri, C.P.; Naoumova, I.; Treviño, L.J.; Shimizu, K.; Li, Y. An empirical test of the trichotomy of values crossvergence theory. Asia Pac. J. Manag. 2020, 37, 65-90. [CrossRef]

102. Egri, C.P.; Ralston, D.A. Generation Cohorts and Personal Values: A Comparison of China and the United States. Organ Sci. 2004, 15, 210-220. [CrossRef]

103. Meriac, J.P.; Woehr, D.J.; Banister, C. Generational differences in work ethic: An examination of measurement equivalence across three cohorts. J. Bus. Psychol. 2010, 25, 315-324. [CrossRef]

104. Ng, E.S.W.; Schweitzer, L.; Lyons, S.T. New Generation, Great Expectations: A Field Study of the Millennial Generation. J. Bus. Psychol. 2010, 25, 281-292. [CrossRef]

105. Vroom, V.H.; Yetton, P.W. Leadership E Decision-Making; University of Pittsburg Press: Pittsburg, PA, USA, 1973.

106. Sen, A.K. On Ethics and Economics; Wiley-Blackwell: Hoboken, NJ, USA, 1991.

107. Friedman, M. The social responsibility of business is to increase its profits. New York Times Mag. 1970, 13, $122-124$.

108. Marechal, J.P. Ethical Economics and Sustainable Development. 2008. Available online: http://www.sens-public.org/articles/50 3/ (accessed on 20 March 2021).

109. Grunert, S.C.; Juhl, H.J. Values, environmental attitudes, and buying of organic foods. J. Econ. Psychol. 1995, 16, 39-62. [CrossRef]

110. Milgrom, P.; Roberts, J. Complementarities and Fit Strategy, Structure, and Organization Change in Manufacturing. J. Account. Econ. 1995, 19, 179-208. [CrossRef]

111. Whetten, D.A.; Felin, T.; King, B.G. The Practice of Theory Borrowing in Organizational Studies: Current Issues and Future Directions. J. Manag. 2009, 35, 537-563. [CrossRef]

112. Nedelko, Z.; Potocan, V. Ethics in public administration: Evidence from slovenia. Transylv. Rev. Adm. Sci. 2013, 9, 88-108.

113. Dansereau, F.; Cashman, J.; Graen, G. Instrumentality theory and equity theory as complementary approaches in predicting the relationship of leadership and turnover among managers. Organ. Behav. Human Perform. 1973, 10, 184-200. [CrossRef]

114. Elrehail, H.; Emeagwali, O.L.; Alsaad, A.; Alzghoul, A. The impact of Transformational and Authentic leadership on innovation in higher education: The contingent role of knowledge sharing. Telemat. Inform. 2018, 35, 55-67. [CrossRef]

115. Hassan, S.; Mahsud, R.; Yukl, G.; Prussia, G.E. Ethical and empowering leadership and leader effectiveness. J. Manag. Psychol. 2013, 28, 133-146. [CrossRef]

116. Chhinzer, N.N.; Currie, E. Assessing longitudinal relationships between financial performance and downsizing. Manag. Decis. 2014, 52, 1474-1490. [CrossRef]

117. Cho, T.; Faerman, S.R.; Shin, M. Employee participation and performance In Korean local government: Mediating effects of individual-level characteristics. Int. Rev. Public Adm. 2012, 17, 45-69.

118. Weber, J. Understanding the Millennials' Integrated Ethical Decision-Making Process: Assessing the Relationship Between Personal Values and Cognitive Moral Reasoning. Bus. Soc. 2019, 58, 1671-1706. [CrossRef] 
119. Al-Mansoori, R.S.; Koç, M. Transformational leadership, systems, and intrinsic motivation impacts on innovation in higher education institutes: Faculty perspectives in engineering colleges. Sustainability (Switzerland) 2019, 11. [CrossRef]

120. Ahlström, H. Policy hotspots for sustainability: Changes in the EU regulation of sustainable business and finance. Sustainability (Switzerland) 2019, 11. [CrossRef]

121. Elkington, J. Enter the Triple Bottom Line. In The Triple Bottom Line: Does It All Add Up; Henriques, A., Richardson, J., Eds.; Earthscan: London, UK, 2004; pp. 1-16.

122. Wang, L.; Juslin, H. The Effects of Value on the Perception of Corporate Social Responsibility Implementation: A Study of Chinese Youth. Corp. Soc. Responsib. Environ. Manag. 2011, 18, 246-262. [CrossRef]

123. González-Rodríguez, M.R.; Díaz-Fernández, M.C.; Simonetti, B. The social, economic and environmental dimensions of corporate social responsibility: The role played by consumers and potential entrepreneurs. Int. Bus. Rev. 2015, 24, 836-848. [CrossRef]

124. Razavi, T. Self-Report Measures: An Overview of Concerns and Limitations of Questionnaire Use in Occupational Stress Research; Department of Accounting and Management Science, University of Southampton: Southampton, UK, 2001.

125. Donaldson, S.I.; Grant-Vallone, E.J. Understanding Self-Report Bias in Organizational Behavior Research. J. Bus. Psychol. 2002, 17, 245-260. [CrossRef]

126. Lau, P.Y.Y.; McLean, G.N.; Lien, B.Y.H.; Hsu, Y.C. Self-rated and peer-rated organizational citizenship behavior, affective commitment, and intention to leave in a Malaysian context. Pers. Rev. 2016, 45, 569-592. [CrossRef]

127. Li, C.; Wu, K.; Johnson, D.E.; Wu, M. Moral leadership and psychological empowerment in China. J. Manag. Psychol. 2012, 27, 90-108. [CrossRef]

128. Homola, J.; Jackson, N.; Gill, J. A measure of survey mode differences. Elect. Stud. 2016, 44, 255-274. [CrossRef]

129. Xing, Y.; Handy, S. Online versus phone surveys: Comparison of results for a bicycling survey. Transp. Plan. Technol. 2014, 37, 554-567. [CrossRef]

130. Baruch, Y. Response Rate in Academic Studies-A Comparative Analysis. Human Relat. 1999, 52, 421-438. [CrossRef]

131. Kidder, L.H. Research Methods in Social Relations; Rinehart \& Winston: New York, NY, USA, 1981.

132. Babbie, E.R. Survey Research Methods; Wadsworth: Belmont, CA, USA, 1973.

133. Nulty, D.D. The adequacy of response rates to online and paper surveys: What can be done? Assess. Eval. Higher Educ. 2008, 33, 301-314. [CrossRef]

134. Dillman, D.A.; Phelps, G.; Tortora, R.; Swift, K.; Kohrell, J.; Berck, J.; Messer, B.L. Response rate and measurement differences in mixed-mode surveys using mail, telephone, interactive voice response (IVR) and the Internet. Soc. Sci. Res. 2009, 38, 1-18. [CrossRef]

135. Shih, T.-H.; Fan, X. Comparing Response Rates from Web and Mail Surveys: A Meta-Analysis. Field Methods 2008, $20,249-271$. [CrossRef]

136. Ardichvili, A.; Jondle, D.; Kowske, B.; Cornachione, E.; Li, J.; Thakadipuram, T. Ethical Cultures in Large Business Organizations in Brazil, Russia, India, and China. J. Bus. Ethics 2012, 105, 415-428. [CrossRef]

137. Martinez-Conesa, I.; Soto-Acosta, P.; Palacios-Manzano, M. Corporate social responsibility and its effect on innovation and firm performance: An empirical research in SMEs. J. Clean. Prod. 2017, 142, 2374-2383. [CrossRef]

138. Hammann, E.M.; Habisch, A.; Pechlaner, H. Values that create value: Socially responsible business practices in SMEs-Empirical evidence from German companies. Bus. Ethics Eur. Rev. 2009, 18, 37-51. [CrossRef] 